\title{
Constructing a Nation Branding Model - the Case of Serbia
}

\author{
Branka Novčić KoraćA* Aleksandra Bradić-Martinović ${ }^{B}$, Branislav Miletićc $^{\mathrm{C}}$ \\ Received: September 04, 2020 | Revised: October 26, 2020 | Accepted: October 29, 2020 \\ doi: 10.5937/gp24-28279
}

\begin{abstract}
This paper aims to understand the concept and fundamental terms related to nation branding as a strategic tool for improving Serbia's international market position, a post-communist and former Yugoslav country. The author intends to gain insight into Serbia's current brand perception as a developing country that can find an opportunity for rebirth and parting with the legacy implementation of the nation branding concept. The quantitative research methods were applied in this paper, and the questionnaire developed for the research investigated the perception of brand Serbia by leaning on Risitano's framework. Our analysis finds that national treasury, people, tourism and business destination were recognized as the most important points for country and nation positioning.
\end{abstract}

Keywords: nation brand; Serbia; nation branding model; tourism

\section{Introduction}

Since the dissolution of great communist states at the end of the $20^{\text {th }}$ century, Europe's landscape has dramatically changed. The turbulent times brought 28 new states in Central and Eastern Europe (CEE) (Ociepka, 2018). For more than 20 years, the new states have been investing wide-ranging and complicated efforts to position themselves on the geographic and mental map of Europe, but also to present themselves to the world as democratic and politically stable countries with developing economies (Hall, 2002; Florek, 2005; Szondi, 2007; Popesku et al. 2010; Aronczyk, 2013; Merkelssen \& Rasmussen, 2016; Novčić Korać \& Šegota, 2017; Cheregi \& Bargaoanu, 2020). The path of transition from a centralised to a market economy, from an authoritarian, one-party system to a multi-party, democratic society, has included the systemic change of a nation's identity and image (Saunders, 2016; Kaneva, 2017; Hedling, 2019). Aronczyk (2013) notes that countries in transition focus on internal problems, and only several years into transi- tion, they start grasping the importance of the image they present externally.

Leading authors in the field of nation branding agree that the CEE countries, due to their similar geographical, economic, political, social system and historical roots, constitute a fertile ground for research and analyses of the undertaken nation branding efforts (Szondi, 2007; Anholt, 2013; Surowiec 2016; Ociepka, 2018). Literature review points that academic researchers and practitioners have analyzed nation branding initiatives in certain Central and Eastern European countries (Konecnik \& Go, 2007; Volcic \& Andrejević, 2011; Surowiec, 2016; Pawlusz \& Polese, 2017; Andrei, 2017; Novčić Korać \& Miletić, 2018). All of the above indicates that the branding of former communist countries, which are today independent nations, has significantly evolved in less than two decades. This fact enabled researchers and practitioners to identify the most frequent challenges, problems and patterns of nation branding applied in CEE countries. Novčić Korać

\footnotetext{
A University in Belgrade, Faculty for organizational sciences, Jove llića 154, 11000 Belgrade, novcic.branka@fon.bg.ac.rs

B Institute of economic sciences, Zmaj Jovina 12, 11000 Belgrade, abmartinovic@ien.bg.ac.rs

c Horwath HTL, Majke Jevrosime 23, 11000 Belgrade, bmiletic@horwathhtl.com

* Corresponding author: Branka Novčić Korać, e-mail: novcic.branka@fon.bg.ac.rs
} 
\& Šegota (2017) argues that nation branding will enable countries in transition to part from the legacy of the former system, change entrenched stereotypes that are often negative or wrong, find and reconstruct the sometimes blurred nation's identity. Considering the significance and benefits that nation branding can bring to countries in transition, especially post-com- munist states, this work will analyse the application of nation branding on the examples of Serbia, a state of former Yugoslavia. Therefore, the paper aims to bring deeper knowledge into construct of nation branding, how it is performed, and what influences various stakeholders' perceptions of a post-communist, ex-Yugoslav and transitioning country.

\section{The case of Serbia}

It is not possible to begin a story about the former Yugoslav states, the emergence of the new nations in the late 20th century and their efforts to create a recognisable image and identity without introducing the roots and creation of Yugoslavia. In the first decades of the 20th century, on the remnants of the Ottoman and Austro-Hungarian empires, the Kingdom of Yugoslavia was formed - the Kingdom of Serbs, Croats and Slovenes (Petranović, 1988), as the central Balkan state (Petranović, 1988). Yugoslavia was a state that brought together South Slavs and other nonSlav communities; the Orthodox, Catholics, Muslims; members of different cultures (Popesku et al., 2010). The geographical position of the Kingdom of Yugoslavia, at the crossroads of the East and West, ensured favorable conditions for economic development and overall progress. After the Second World War, there was a government change, and the monarchy and the Kingdom of Yugoslavia ceased to exist. With Josip Broz Tito at the helm, there emerged the Socialist Federal Republic of Yugoslavia (SFRY) (Novčić Korać \& Miletić, 2018). The author further observes that the SFRY was a community of five peoples that lived in six republics: Slovenia, Croatia, Bosnia and Herzegovina, Serbia, Montenegro and Macedonia. With the change of the state entity, a new ideology was introduced, socialism. The new social and economic system based on socialism and communism directly reflected in the changes in social values, customs, myths, and patterns of behaviour that were considered socially acceptable.

Throughout history, Serbia was part of several large state entities: the Kingdom of Yugoslavia; the Feder- al People's Republic of Yugoslavia; the Socialist Federal Republic of Yugoslavia; the Federal Republic of Yugoslavia and the State Union of Serbia and Montenegro (Mulec \& Wise, 2012). As a consequence of the turbulent political and social past, Serbia changed its name several times for almost a century. Finally, on 5 June 2006, the National Assembly declared the independence of the Republic of Serbia. Thus, Serbia's newly-formed state restored the name last used during the time of the Kingdom of Serbia and simultaneously launched the process of seeking the identity of the nation, which was subordinate to the identity of the broader community in the time of Yugoslavia. Similarly to other former Yugoslav countries, after declaring independence, Serbia faced the challenges of positioning the nation and improving the image and reputation (Novčić Korać \& Šegota, 2017).

However, the journey towards an independent Serbia was marked by dynamic historical, political and economic changes, the civil war, international sanctions and NATO bombing, which significantly contributed to creating a negative picture and image of Serbia as "a bad guy" (Kaneva, 2017; Cvijanović et al., 2018). Although it may seem that almost all negative associations linked to the nations involved in the conflicts disappeared with Yugoslavia, some associations continued to haunt the young states, including Serbia. Apart from the significantly tarnished image, Serbia was faced with its nation brand's poor recognisability on the international scene. However, Serbia was probably facing an even bigger problem internally - unclear, inconsistent and somewhat confusing perceptions of Serbia's identity seen by its nationals.

\section{Branding Serbia}

Defining the newly-formed nations' identity gained in importance with the end of the conflict in the former Yugoslavia and became one of the main imperatives of the young states. As a need to separate from the past and Yugoslavia, young people seek and recognize a somewhat forgotten identity, returning to their roots, history and tradition. It was in this period that nation branding began being recognised as the way to improve the tarnished image and forgotten identity of Serbia. Dwyer et al. (2016) note that in the 1990s, ethnic identity was used in Serbia as a tool for seeking national identity, often with a political purpose. The author further observes that the historical legacy was the primary source and constituent element of 
the Serbian nation's forgotten identity. The first initiatives on this topic emerged with the recognition of the importance of a strategic approach to nation branding (Novčić Korać \& Šegota, 2017).

Similarly to most states of the former Yugoslavia, the simplest way for the government bodies to start the complex process of nation branding was to launch initiatives in tourism and present Serbia as an attractive tourism destination. In the late 1990s, the National Tourism Organisation of Serbia (NTOS) presented a promotional brochure, under the slogan "Serbia: Landscape painted from the heart", where mainly elements of ethnic identity were woven into the presentation of Serbian tourism (Novčić Korać \& Šegota, 2017). In the publication by NTOS, the term 'landscape' was described with nature and culture. Apart from the landscape, the Serbian, Orthodox tradition was also emphasized, while other communities' cultures and traditions were presented only symbolically (Cvijanović et al., 2018). The change of the political regime at the start of the new millennium brought about a shift in nation's branding direction. In 2000, the new state administration hired the advertising agency Saatchi and Saatchi, to create a new promotional campaign for Serbian tourism. Presenting Serbia as a multi-ethnic country (Paunović, 2014) made the new tourism campaign's backbone.

During the early 2000s, the Serbian state administration invested considerable efforts to improve Serbia's image, strengthening the country and nation's position among Western European countries and attracting foreign investment (Kaneva, 2017). The efforts resulted in the first systematically conceived and strategically created initiative at a national level, aimed at improving Serbia's image globally and building the nation brand. With the idea of creating nation brand, in 2006, the Government of Serbia and the Ministry of Foreign Economic Relations published a call for consultants and agencies that would help improve the nation's image and create a branding platform (Novčić \& Štavljanin, 2015). Many leading nation branding experts, including Simon Anholt, were interested in joining the project. In late 2006, the Government's initiative established a state body called the Council for Serbia's Promotion, colloquially known as the Council for Branding of Serbia. The main goal of forming the Council was to create the National Strategy for the Promotion of Serbia that the Government would later adopt.

In cooperation with the NTOS, the Council and the Ministry of Trade and Tourism launched two promotional videos for presenting Serbia's tourist offer, under the slogan "Sights and Sounds of Serbia" and as part of the campaign "Moments to Remember". The first video was screened on CNN Today in 2007 (Mulec \& Wise, 2012). However, the work of the Council for Branding of Serbia was followed by many controversies, partly stemming from the inadequate communication of essential information related to its mission and expected outcomes. Although the Council launched several initiatives, such as hosting the Eurosong 2008 and the Summer Universiade 2009, the undertaken efforts had a short-term effect. The media and political turmoil related to the Council's work led to animosity on the general public's part towards the Council and the entire nation branding concept (Paunović, 2014). In a short period, the Council was dismantled. This occasion led to a shift in the state administration's focus from developing and implementing the nation branding strategy and setting the strategic framework for Serbia's promotion to higher priority issues for the country. Today, the branding initiatives focus primarily on presenting Serbia as a tourism destination, with the NTOS at the helm of almost all initiatives. Since 2015, the main focus of NTOS promotional campaigns have been divided into two streams, and the internal campaign called "My Serbia" and the external campaign "The Danube in Serbia: 588 Impressions" (Novčić Korać \& Šegota, 2017).

Just as an increasing number of governments turn to the marketing and branding techniques to emphasize their differential advantages, Serbia also needs to embrace nation branding as a strategic goal at a national level. Some of the main problems arising in the implementation of nation branding in Serbia are false understanding of the concept, insufficient commitment, complexity, a large number of stakeholders and the lack of a solid model (Novčić Korać \& Miletić, 2018). Hence, this research aims to provide the conceptualization of the Serbia nation branding model.

\section{Conceptualization of nation branding model}

For this research's purpose, the destination branding model developed by Risitano (2006) was a starting point for the conceptualization of the Serbia nation branding model. Risitano's model, presented below, as a result of the author's work on the branding platform for regional park Campi Flegrei, an area west from Naples's city in Italy. Campi Flegrei is famous as a vol- canic region rich in archaeological sites and insufficiently researched and inadequately communicated destination.

The model analyzes the place brand from the point of brand creators (who initiate communication) and the brand "consumer" (brand users, communication recipients). The brand creators are in charge of defin- 


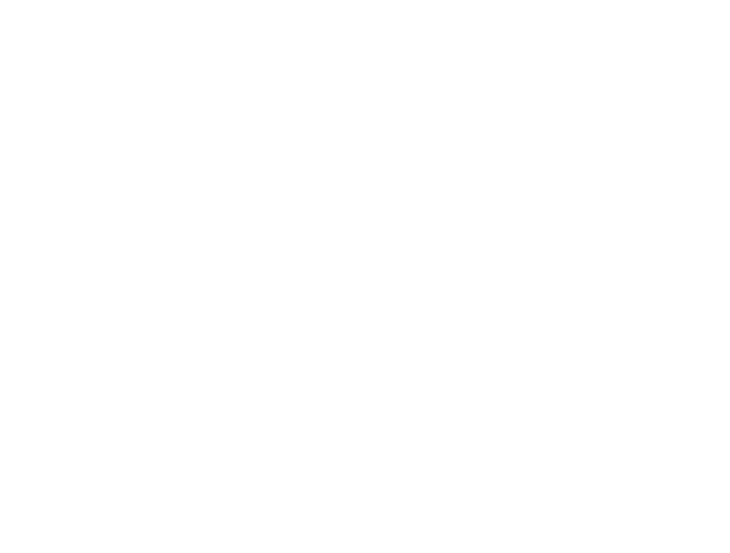

Figure 1. Destination branding model Source: Risitano (2006)

ing, selecting and developing the elements of place brand identity such as brand name, slogan, personality, character, culture and symbols. The designed elements of brand identity that are in line with the current perception and the brand's desired position are based on a place's unique brand values. Therefore, the elements of brand identity are only manifestations of the defined brand values. Place brand creators, on the other hand, are also obliged to analyse how various brand consumers perceive the selected values by determining current brand perception, analysing brand knowledge, brand association, brand image and brand awareness. Both aspects of the model are equally important, but Risitano underlines that the creation of a relevant place brand needs a focus on the core of the model - the brand identity of a place. The essence of brand identity in the model consists of identifying brand perspectives and points of difference, which are the foundation for developing a brand positioning strategy.

Having everything said, Risitano's model was found to be the only theoretical model that comprehends both internal and external perspectives of place brand creation and management and gives an overall understanding of what place/nation branding exactly means. Compared to other available models and indexes, Risitano's model proved to be very useful when analyzing different perspectives of place branding above all because of its complex and layered approach (Popesku et al. 2010). Therefore, Risitano's model of destination branding was found to apply to different levels of place brands (Novčić Korać \& Šegota, 2017), more specific to nation branding and due to this, the model was chosen as a basis for the development of Serbia nation branding model. The initial branding model was adapted to the nation branding concept and tested in this research.

To start developing a nation brand, it is first necessary to determine the nation's current perception and evaluate the initial position. In their work, Bolin (2016) and Hedling (2019) highlight the short-term effects of destination brand development and management, focusing only on inputs from one group of stakeholders. To get the whole picture of a brand's current perception and determine the points of difference for Serbia's brand identity, internal and external stakeholders are examined. The starting point for the survey conduct in this research is that the internal and external perception of the key elements of the brand identity directly affects the positioning of Serbia. After examining the available literature on nation branding, we conclude that there is a small number of original research papers and projects on Serbia's branding, which makes this topic insufficiently explored and particularly interesting for further research. Also, we found that perceptions of brand Serbia have not been examined (quantitatively or qualitatively), nor has the nation's image been presented from various groups of stakeholders' viewpoints. Also, there are no research papers that identify the key points of difference for Serbia's brand or those proposing a nation branding model for Serbia. Identifying the key points of difference for the nation brand and defining the nation branding model for Serbia could enable the development of an adequate strategy for improving the market position and perceptions of Serbia's image on the international stage. Moreover, it has been concluded that there is no systematic approach to branding Serbia at a higher institutional level, intending to improve the global market position. The paper aims to gain insight into Serbia's current brand perception, a developing country, which can find an opportunity for rebirth and parting with previous legacy in the implementation of the nation branding concept. This research also aims to reveal and understand the hidden structure of brand Serbia from internal and, even more important, external stakeholders. The paper's main idea is to propose a Serbia nation branding model, built upon internal and external stakeholder perception.

\section{Methodology}

Quantitative research with statistical methods is applied to a satisfactory sample (greater than 150 participants) and provides results with a satisfactory level of significance (Nath, 2007). Quantitative methods determine internal and external brand identity models and identify the dominant values (points of difference) of brand Serbia, which create the Serbia nation branding model. 
Serbia's internal and external perception was conducted in four states for three and a half years, from October 2011 to April 2015. Bearing in mind that the first part of the survey included respondents in three foreign countries (external stakeholder groups), external research was conducted in the following three stages:

1. October 2011, SLOVENIA ( $=2,063)$;

2. November 2013 - July 2014, ITALY ( $\mathrm{N}=323)$;

3. May 2014 - February 2015, AUSTRIA (N=317).

The second part, the internal research, was carried out in Serbia in March and April 2015. The survey among internal stakeholders was conducted via the Internet, using online questionnaires, and the call to participate was advertised on social networks Facebook, Twitter and LinkedIn. In informing the respondents about the survey, companies' and specialized organizations' mailing lists were used. Influential bloggers and forums also free willingly posted a call to participate in the survey. The research sparked great interest and positive comments by the internal public as it explores a hot topic - Serbia's branding. In a survey of Serbia's internal perceptions over 25 days, 1,710 responses, of which 1,650 valid (96.5\%) were collected.

\section{Questionnaire}

The primary tool for collecting data is an online questionnaire. The questionnaire was designed upon Risitano's (2006) work, which proposed a theoretical framework for analyzing nation brand identity elements. The questionnaire consists of seven clusters of questions: 1. General questions - demography referring to gender, age, educational background, employment, citizenship, and consumer behavior when using a brand (purpose and frequency of visits); 2. Brand culture - important features of culture, seen from two aspects: a) culture of a nation (Serbs): "spirit" of people, tradition, important events, gastronomy, etc. and b) culture of a country (Serbia): cultural heritage, historical landmarks, monuments, archaeological sites, monasteries and churches; 3 . Brand personality - describing the nation as a person with demographic characteristics such as gender and age; 4) Brand character - exploring the perceived character of a brand; 5) Brand symbols - the elements that fundamentally determine the brand, primary and secondary brand associations (famous people, events, landmarks, cities, music groups, etc.); 6) Brand name - associate ions to brand name in terms of uniqueness, strength, and recognition; and 7) Brand slogan - recall and recognition of brand slogan.

The questionnaire designed for internal and external research includes a combination of open and closed questions. The final questionnaire for internal research consists of 7 open, 11 closed questions and 38 attitudinal statements, while the questionnaire designed for external study contains an additional closed question. The questionnaire consists of a relatively large number of attitudinal statements on several frequent stereotype attitudes shared in the discourse of everyday communication, media, history and the collective consciousness of the Serbs. Attitudinal statements were collected over 12 months from national media (TV and newspapers) and ten focus groups (Novčić et al., 2012). Within ten focus groups, where representatives of all social segments participated, previously collected attitudinal statements were tested, and only appropriate ones were chosen for the research. In confirmatory research, PCA was used to distinguish the significant from the insignificant elements of Serbia brand identity and reveal the hidden structure of the brand. To measure attitudes, a five-item Likert scale was used with strongly disagree - weight of 1 , and strongly agree - weight of 5 , as the scale anchors and "I don't know" answer was offered as well. Closed questions exploring brand personality (gender, age and brand letter) and brand symbols (state symbols: national flag colors, state amblem and moto) were measured based on predefined answers. Within this group of questions, "I don't know" answer was also offered. The questionnaire's form and structure were the same in all countries covered by the research, with minor variations depending on whether the questionnaire was intended for the internal or external survey. In the survey conducted in Italy, Austria and Slovenia, the questionnaires were translated into those countries' official languages.

\section{Sample and sampling}

Respondents were divided into two groups, internal and external stakeholders. The population within the first group of respondents consists of internal stakeholders (members of the Nation), primarily Serbian residents. According to official data, in January 2014, the estimated size of Serbia's population was 7,146,759 (Statistical Office of RS, 2014). Data analysis indicated that the Serbian nation members with a permanent residence in another country also participated in the survey. The diaspora was included in Serbia brand perception research because it counts around 4 million Serbs (Ministry of Foreign Affairs of the Republic of Serbia, 2014), as well as due to Serbia's economic dependence on the diaspora. National Bank of Serbia (2013) states that the diaspora in 2012 sent Serbia 1.73 billion Euros, equivalent to 6.5\% of GDP. For these reasons, internal perception research included all members of the Serbian nation older than 18 (residents of Serbia and the diaspora), regardless of residence. 
The second group of respondents included the most important external stakeholders for Serbia, which significantly impacted the creation and presentation of Serbia's image in Europe and the world. External stakeholders involved in the study consisted of business class members in Italy, Austria and Slovenia. The main criteria for the selection of the three countries were: number of direct foreign investments in Serbia, economic relations (the value of exports and imports), business cooperation (number of foreign companies operating in Serbia), the frequency of visits, and historical, cultural and social tie. There are over 500 Italian companies doing business in Serbia (Serbian Chamber of Commerce, 2013). In the first half of 2014, Italy was Serbia's number one trading partner, first by the value of exports (1.43 million dollars) and second by imports (1.23 million dollars) (PKS Milano Info, 2014). On the other hand, Austria is the largest single foreign investor and secondlargest by the number of companies (around 400), directly or through representatives operating in Serbia (SIEPA, 2014; Serbian Chamber of Commerce, 2015). Italy, Austria and Slovenia are the three leading partners of Serbia in the number of projects and value of investments (SIEPA, 2014).

Several sampling techniques were applied in the study. For online research, a combination of convenient and snowball sample was applied, and random online sampling. Samples in all countries surveyed are three-digit, stratified according to the criteria of gender, age and educational level. A total number of 4,353 responses was acquired: 2,703 external and 1,650 internal survey.

\section{Surveying techniques}

For the online survey, the questionnaire was created using the online survey tool www.kwiksurveys. com. In implementing the research in Italy, Austria and Slovenia, the participants were informed about the survey through social networks and mailing lists. The questionnaire and survey were advertised on professional social networks (such as LinkedIn), and in groups of business associations, in the countries covered by the survey. Also, information about the research and a link to the survey were posted on pro- fessional associations' websites. In conducting the research in Italy, Austria and Slovenia, of great importance were business contacts and mailing lists obtained from the consulate and Economic Attaché in the Embassy of the Republic of Serbia. As a result, the research was supported by the Embassy of the Republic of Serbia in Italy and Austria, which added value to the research and contributed to a large number of responses. Serbian Chamber of Commerce, with its representative offices, along with the Austrian and Italian Chamber of Commerce also supported the research by providing their business contact lists.

In order to determine the current state of internal and external perception of brand Serbia and to reveal the hidden structure of brand Serbia, several statistical tools were applied. Data collected through internal and external research were coded, entered and analyzed using SPSS 21.0. Guided by Pallant (2007) good practice and Malhotra (2007), data screening was performed before data analysis to check for possible errors, incomplete data, and delete duplicate responses. After data screening was completed, it was proceeded to data processing using the following statistical tools:

1. Descriptive statistics (mean, mode, standard deviation, frequency analysis) determine the average values of the investigated problem.

2. Explorative factor analysis - EFA, principal component analysis (PCA) was used to reveal the hidden structure of brand Serbia and to discover dominant elements of Serbia's brand identity. To establish the optimal number of factors, a parallel analysis was conducted using the Monte Carlo simulation. Having determined the optimal number of factors, EFA identified the dominant elements and variables that constitute brand Serbia. The ultimate goal of factor analysis was to identify elements of the nation brand identity that are reliable and can be interpreted in each of the samples. Based on the results, EFA identified the main components, variables and their interrelations, which created internal and external brand identity models. Serbia brand identity models and the Serbia nation branding model were created based on the results of EFA.

\section{Data analysis}

The final survey sample consisted of 4,353 examinees (2,703 external samples and 1,650 internal sample - Serbian nationals). All four groups in terms of size, were suitable for PCA. As this study aimed to reveal the hidden structure of brand Serbia and determine the dominant elements (points of difference) in internal and external stakeholders' perception, the first step was to split the dataset into four groups - internal (Serbian nationals) and external stakeholders: Italy, Austria and Slovenia, and conduct separate analyses. Based on the obtained results, the second step was to propose internal and external brand identity models for Serbia, which will serve as a foundation for the development of the Serbia nation branding model in the final step. 


\section{Brand identity analysis - external perception}

The external sample was divided into three groups: Italy, Austria and Slovenia and analyzed separately to perform suitable PCA. After the results from all three groups were obtained, they were compared, and the external brand identity model was proposed.

Italy - The examined Italian sample $(\mathrm{n}=323)$ was, on average, 41.37 years old (SD 10.366, median 40, mode 40 , range 23-71 years). Before performing PCA, data were assessed for suitability, PCA was performed five times, and all attitudinal statements with communalities below .5 were excluded. After the final PCA iteration, 17 out of 38 attitudinal statements were left with communalities exceeding .5 and PCA was then entirely performed (see Table 1 ).
Table 1. PCA indicators for Italy

\begin{tabular}{|l|c|}
\hline Indicators & Values \\
\hline No. of variable (communalities < 0.5) & 17 \\
\hline KMO & .894 \\
\hline Bartlett's test & .000 \\
\hline No. of factors & 6 \\
\hline Parallel analysis (final number of factors) & 4 \\
\hline Total variance explained & $64.9 \%$ \\
\hline
\end{tabular}

Source: authors calculation

The obtained four-component solution explained $64.9 \%$ of Serbia brand structure, and all elements met the minimum requirements of reliability. Therefore, it was proceeded to data interpretation (see Table 2 for the results of PCA). After a detailed analysis of the Italian perception of brand Serbia, the following four elements (components) of Serbia brand identity were identified and named: C1) People and mentality, C2) Business destination, C3) Media influence and C4) National treasures.

Table 2. Serbia brand identity Italian perception - rotated component matrix for PCA with Oblimin rotation for 4 factors solution

\begin{tabular}{|c|c|c|c|c|c|}
\hline \multirow[t]{2}{*}{ Attitudinal statements } & \multicolumn{4}{|c|}{ Pattern/structure coefficients } & \multirow[t]{2}{*}{ Comm. } \\
\hline & $\mathrm{C} 1$ & $\mathrm{C} 2$ & C3 & $\mathrm{C} 4$ & \\
\hline Serbs love to know everything & .777 & -.091 & .034 & -.009 & .651 \\
\hline Serbs love folk music & .768 & -.012 & -.026 & -.026 & .576 \\
\hline Serbs are good lovers & .731 & -.187 & -.017 & -.046 & 619 \\
\hline Serbs are greeting with three fingers & .724 & .023 & .026 & .098 & .592 \\
\hline Celebrations play vital role in the lives of Serbians & 675 & .028 & .003 & .211 & .623 \\
\hline Serbia is safe and secure & .101 & -.821 & -.021 & -.029 & .719 \\
\hline Serbia is a country in which one should invest & .096 & -.795 & .037 & -.106 & .622 \\
\hline Serbia is a country of hospitality & .101 & -.742 & -.061 & .176 & .769 \\
\hline Serbia is a country I would recommend to every foreign visitor & -.076 & -.701 & -.067 & .128 & .551 \\
\hline Serbia is a country with high-quality products & .170 & -.546 & .057 & .166 & .514 \\
\hline The image of Serbia in media is better than reality & .060 & .083 & .769 & .025 & .606 \\
\hline The image of Serbia in the media is positive & -.210 & -.323 & .769 & .011 & .664 \\
\hline Serbia is as presented by the foreign media & .151 & .256 & .692 & -.037 & .570 \\
\hline Serbia is rich in monuments & -.014 & -.001 & -.021 & .894 & .790 \\
\hline Serbia is rich in nature beauties & -.079 & -.026 & .032 & .825 & .638 \\
\hline Serbia is rich in archeological sights & .113 & -.036 & .010 & .814 & .791 \\
\hline \multirow[t]{2}{*}{ Serbia is rich in monasteries } & .143 & -.002 & -.024 & .778 & .738 \\
\hline & $\mathrm{C} 1$ & $\mathrm{C} 2$ & C3 & $\mathrm{C} 4$ & \\
\hline$\%$ of variance explained & 36.9 & 10.9 & 9.5 & 7.6 & \\
\hline Cronbach alpha & .832 & .848 & .600 & .879 & \\
\hline Mean & 4.26 & 3.73 & 2.40 & 4.18 & \\
\hline St. deviation & 1.39 & 1.43 & 1.03 & 1.28 & \\
\hline
\end{tabular}

Source: authors calculation 
Austria - A total of 317 representatives of the Austrian business class, participated in the survey. The sample's average age was 40.6 years (SD 11.442, median 39.50 , mode 29 , range 23-73 years). Data were checked for suitability, PCA was performed five times, and 12 attitudinal statements were left with communalities higher than 0.5 . After that, PCA was fully performed (for PCA indicators, see Table 3), and the final results revealed four brand identity elements.

Table 3. PCA indicators for Austria

\begin{tabular}{|l|c|}
\hline Indicators & Values \\
\hline No. of variable (communalities < 0.5) & 12 \\
\hline KMO & .807 \\
\hline Bartlett's test & .000 \\
\hline No. of factors & 6 \\
\hline Parallel analysis (number of factors) & 4 \\
\hline Total variance explained & $67.31 \%$ \\
\hline
\end{tabular}

Source: authors calculation

The results which emerged from PCA on Austrian perception explained almost $70 \%$ of Serbia brand structure, and all elements met the minimum requirements of reliability. After a detailed analysis of the obtained results, data were interpreted (see Table 4 for results of PCA), and four elements (components) of Serbia brand identity were identified: C1) National treasures, C2) Business destination, C3) Media influence, and C4) People and mentality.

Slovenia - The Slovenia sample consisted of 2,063 representatives of the Slovenian business class, with an average age of 41.35 (SD 43.860, median 40.00, mode 35 , and range 22-74 years). Before the application of PCA, the suitability of data for factor analysis was assessed. PCA was repeated three times to exclude attitudinal statements with communalities lower than 0.5 , until 16 attitudinal statements were left. PCA was then fully performed (see Table 5).

Table 5. PCA indicators for Slovenia

\begin{tabular}{|l|c|}
\hline Indicators & Values \\
\hline No. of variable (communalities < 0.5) & 16 \\
\hline KMO & .759 \\
\hline Bartlett's test & .000 \\
\hline No. of factors & 7 \\
\hline Parallel analysis (number of factors) & 5 \\
\hline Total variance explained & $66.3 \%$ \\
\hline
\end{tabular}

Source: authors calculation

The results of factor analysis uncovered a simple and straightforward structure of elements that constitute Serbia's brand identity (for results of PCA, see Table 6). As the final result, a five-element (component) solution emerged, obtained results were interpreted,

Table 4. Serbia brand identity Austrian perception - rotated component matrix for PCA with Oblimin rotation for 4 factor solution

\begin{tabular}{|c|c|c|c|c|c|}
\hline \multirow[t]{2}{*}{ Attitudinal statements } & \multicolumn{4}{|c|}{ Pattern/structure coefficients } & \multirow[t]{2}{*}{ Comm. } \\
\hline & C1 & $\mathrm{C} 2$ & C3 & $\mathrm{C} 4$ & \\
\hline Serbia is rich in monuments & .840 & -.048 & .016 & .052 & .729 \\
\hline Serbia is rich in archeological sights & .824 & -.056 & .003 & .116 & .739 \\
\hline Serbia is rich in nature beauties & .794 & .045 & .039 & -.101 & .622 \\
\hline Serbia is rich in monasteries & .771 & .071 & -.009 & -.046 & .598 \\
\hline Serbia is safe and secure & -.020 & .884 & -.053 & .020 & .768 \\
\hline Serbia is country with high-quality products & .184 & .681 & .044 & .142 & .638 \\
\hline The image of Serbia in media is better than reality & .118 & -.126 & .836 & .052 & .765 \\
\hline Serbia is as presented by the foreign media & .022 & -.074 & .780 & .158 & .672 \\
\hline The image of Serbia in media is positive & -.030 & .423 & .616 & -.158 & .598 \\
\hline Serbs love to know everything & .094 & -.076 & -.009 & 819 & .714 \\
\hline Serbs are good lovers & -.071 & -.009 & .160 & .754 & .598 \\
\hline \multirow[t]{2}{*}{ Serbs are nicely up brought } & .058 & .349 & -.086 & .661 & .636 \\
\hline & C1 & $\mathrm{C} 2$ & $\mathrm{C} 3$ & $\mathrm{C} 4$ & \\
\hline$\%$ of variance explained & 33.96 & 11.46 & 11.35 & 10.54 & \\
\hline Cronbach alpha & .831 & .654 & .687 & .688 & \\
\hline Mean & 4.46 & 3.41 & 3.17 & 4.17 & \\
\hline St. deviation & 1.31 & 1.47 & 1.63 & 1.57 & \\
\hline
\end{tabular}

Source: authors calculation 
Table 6. Serbia brand identity Slovenian perception - rotated component matrix for PCA with Oblimin rotation for 5 factor solution

\begin{tabular}{|c|c|c|c|c|c|c|}
\hline \multirow[t]{2}{*}{ Attitudinal statements } & \multicolumn{5}{|c|}{ Pattern/structure coefficients } & \multirow[t]{2}{*}{ Comm. } \\
\hline & C1 & $\mathrm{C} 2$ & C3 & C4 & $\mathrm{C} 5$ & \\
\hline Serbia is rich in archeological sights & .876 & -.009 & .077 & .011 & .130 & .709 \\
\hline Serbia is rich in monuments & .803 & .020 & .031 & -.016 & -.093 & .714 \\
\hline Serbia is rich in nature beauties & .782 & -.023 & -.046 & -.021 & -.012 & .619 \\
\hline Serbia is rich in monasteries & .731 & .018 & -.061 & .020 & -.093 & .595 \\
\hline Serbia is safe and secure & .001 & .856 & -.008 & .072 & .029 & .704 \\
\hline Serbia is a country of comfort food & .008 & .825 & .007 & .167 & .002 & .632 \\
\hline Serbia is country of hospitality & -.032 & .688 & -.011 & -.172 & -.047 & .571 \\
\hline When mentioning Serbia, I only have nice associations & .028 & .594 & .004 & -.255 & .011 & .503 \\
\hline Serbia is as presented by the foreign media & .011 & -.007 & .907 & .002 & .007 & .823 \\
\hline Serbia is as presented by the domestic media & -.004 & .008 & .906 & -.004 & -.028 & .825 \\
\hline Serbia is modern and developed & .004 & -.048 & -.009 & -.882 & -.007 & .758 \\
\hline Serbia is European country & -.026 & .051 & .013 & -.805 & -.012 & .672 \\
\hline Serbia is mainly urban & .023 & .011 & -.004 & -.733 & .028 & .544 \\
\hline Church plays vital role in lives of Serbian people & .001 & .016 & -.051 & -.017 & -.846 & .687 \\
\hline Celebrations play vital role in the lives of Serbians & -.043 & -.019 & .091 & -.001 & -.832 & .714 \\
\hline \multirow[t]{2}{*}{ In Serbia, tradition is specially nurtured } & .076 & -.001 & -.020 & .029 & -.698 & .531 \\
\hline & $\mathrm{C} 1$ & $\mathrm{C} 2$ & C3 & C4 & C5 & \\
\hline$\%$ of variance explained & 20.2 & 18.0 & 10.4 & 9.4 & 8.3 & \\
\hline Cronbach alpha & .819 & .742 & .791 & .746 & .717 & \\
\hline Mean & 3.61 & 3.95 & 2.59 & 2.55 & 4.05 & \\
\hline St. deviation & .85 & .89 & .88 & .82 & .84 & \\
\hline
\end{tabular}

Source: authors calculation

and elements of brand identity were identified in the following way: C1) National treasures, C2) Tourism destination, C3) Media influence, C4) Underdevelopment, and C5) Cultural heritage.

\section{Brand identity analysis- internal perception}

The surveyed Serbian nationals were $(n=1,650)$, on average 31.73 years old (SD 31.324, median 31, mode 30, range 19-76 years). Before performing PCA, the suitability of data for factor analysis was assessed. PCA was repeated six times with the exclusion of attitudinal statements with communalities lower than 0.5. From the initial 38 attitudinal statements, 13 were suitable. PCA was then fully performed (for more details, see Table 7).
Table 7. PCA indicators for Serbia

\begin{tabular}{|l|l|}
\hline Indicators & Values \\
\hline No. of variable (communalities < 0.5) & 13 \\
\hline KMO & .756 \\
\hline Bartlett's test & .000 \\
\hline No. of factors & 5 \\
\hline Parallel analysis (number of factors) & 5 \\
\hline Total variance explained & $66.6 \%$ \\
\hline
\end{tabular}

Source: authors calculation

The obtained results met the minimum requirement of reliability for all of the five elements and it has proceeded to the interpretation of results. As Table 8 shows, factor analysis revealed Serbia's hidden structure brand, which was very simple. Based on the results obtained from factor analysis of the internal perception of brand Serbia and supported by a reliability test, it could be concluded that the most dominant elements of brand identity were: 1) National treasures, 2) Distorted image, 3) Tourism destination, 4) Media influence and 5) People. 
Table 8. Serbia brand identity Serbian perception -rotated component matrix for PCA with Oblimin rotation for 5 factor solution

\begin{tabular}{|l|c|c|c|c|c|c|}
\hline \multirow{2}{*}{ Attitudinal statements } & \multicolumn{3}{|c|}{ Pattern/structure coefficients } & Comm. \\
\cline { 2 - 7 } & C1 & C2 & C3 & C4 & C5 & \\
\hline Serbia is rich in monuments & .829 & -.010 & -.009 & -.004 & -.232 & .631 \\
\hline Serbia is rich in archeological sights & .801 & -.002 & -.007 & .029 & -.035 & .655 \\
\hline Serbia is rich in monasteries & .733 & .024 & .008 & -.039 & .153 & .608 \\
\hline Serbia is rich in nature beauties & .637 & -.023 & .070 & .017 & .232 & .569 \\
\hline The image of Serbia in media is positive & .005 & .858 & .124 & -.028 & -.015 & .721 \\
\hline The media image of Serbia is better than reality & -.006 & .825 & -.125 & .015 & -.001 & .735 \\
\hline Serbia is safe and secure & -.065 & -.040 & .816 & -.028 & -.163 & .649 \\
\hline Serbia is country of hospitality & .036 & .065 & .733 & .058 & .185 & .669 \\
\hline Serbia is country I would recommend to every foreign visitor & .124 & -.009 & .716 & .013 & .116 & .600 \\
\hline Serbia is as presented by the domestic media & .031 & -.063 & .066 & -.883 & .084 & .703 \\
\hline Serbia is as presented by the foreign media & -.033 & .094 & -.088 & -.765 & -.086 & .680 \\
\hline Serbs are talented for sports & .016 & -.021 & -.005 & .007 & .833 & .676 \\
\hline Serbs are beautiful nation & -.012 & -.020 & .045 & -.005 & .810 & .758 \\
\hline & $\mathrm{C1}$ & $\mathrm{C2}$ & $\mathrm{C3}$ & $\mathrm{C4}$ & $\mathrm{C5}$ & \\
\hline \% of variance explained & 25.7 & 113.4 & 10.9 & 8.4 & 8.1 & .647 \\
\hline Cronbach alpha & .747 & .595 & .669 & .540 & .627 \\
\hline Mean & 4.24 & 2.63 & 2.40 & 2.27 & 4.27 & \\
\hline St. deviation & .87 & 1.14 & .95 & 1.01 & .82 & \\
\hline
\end{tabular}

Source: authors calculation

\section{The proposition of a nation branding model}

At the core of every branding model are brand values that fundamentally determine and differentiate the brand. Accordingly, the foundation for developing a nation branding model is to define the key values and unique brand elements that would indicate the areas for brand Serbia to focus. Therefore, the Serbia nation branding model development's foundation would be external and internal brand identity models (see Figure 2). Quantitative research helped identify internal and external brand identity models propositions, and they will be used to develop the Serbia nation branding model.

Serbia brand identity model - external perception The hidden structure of external brand perception pointed to elements with a dominant position in external respondents' organized knowledge about Serbia. Elements identified as the most important in Italy, Austria and Slovenia represent inputs for Serbia's external brand identity model. Respondents in all countries covered by the research are unanimous, outlining national treasures and media influence as the most important brand Serbia elements. Aside from those as mentioned above, it was discovered that external stakeholders recognize Serbia as a desirable business
(Italy and Austria) and tourism (Slovenia) destination, so both components found its place in the model. The Serbian nation (people) and specific Serbian mentality are the least important elements of brand Serbia. In order to position Serbia in Italy, Austria and Slovenia, Serbia external brand identity model proposition should consist of the following elements:

1. National Treasures. Identified as the most recognizable element and the most dominant value of Serbia and is defined by monuments, archaeological sites, monasteries and natural beauties. National treasures are related to all elements in the model and directly impact the element "business and tourism destination".

2. Media INFLuence. Although it may seem like the media do not find its rightful place in the nation brand identity model, one needs to bear in mind that media have the most substantial influence on creating Serbia's awareness and image among external stakeholders. The second-place element in the model confirms the role of media in creating and presenting image externally. Foreign media who project bias, negative and unrealistic images represent the main source of information for Serbia and Serbs' external stakeholders. For this rea- 

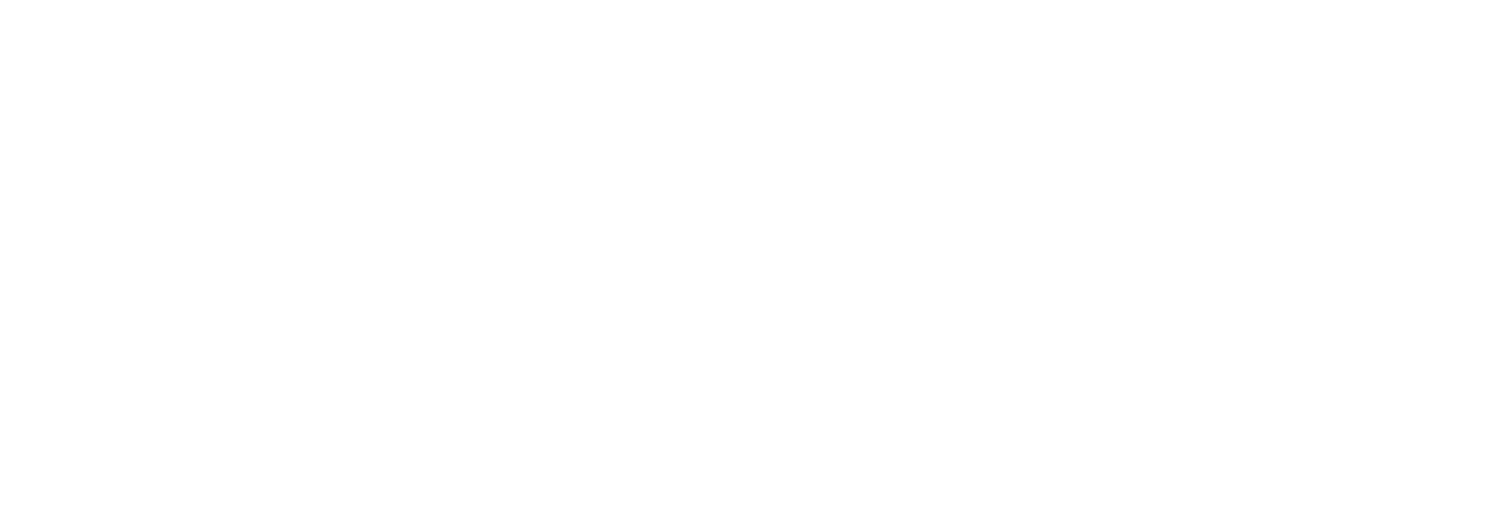

Figure 2. Serbia brand identity models proposition

son, foreign media influence is directly connected to other elements in the model, shaping the representation of the Serbian nation, national treasures, tourism and business opportunities.

3. Business AND TOURISM DESTINATION. Serbia's potential as a business and tourism destination is also recognized in the model and defined by the following characteristics: safe and secure, hospitable, high-quality products, recommendation, investment potential and gourmet cuisine. Due to the complex nature of the element "business and tourism destination", all factors in the model directly influence the element.

4. People ANd mentality. The Serbian nation is perceived as inquisitive people, good lovers, and people whose lives celebrations have an important place. This element's very nature points out the impact and roles that people have in creating a tourism and business destination and in the presentation of national treasures.

Of great importance for the brand identity model's development are roles and relations between the selected elements and their pertaining variables.

\section{Serbia brand identity model - internal perception}

The results from the exploratory factor analysis on internal stakeholders' attitudes and opinions referred to an invisible structure of brand Serbia seen through the Serbian nation's eyes. The internal perception results revealed a slightly different structure of brand Serbia and gave a new dimension to the observed phenomenon. Analysis of internal perception discovered the following dominant elements of brand Serbia:

1. National treasures. The most dominant element of brand Serbia, with the same place, role and relations with variables (archaeological sites, monuments, monasteries and natural beauties) as in the external perception model.
2. Distorted image. The next element by importance in the model is a distorted image that holds an important place in internal stakeholders' consciousness. The projection of the distorted, negative and unrealistic image has a strong, direct influence on image creation and presentation of Serbia as a tourism destination.

3. Tourism Destination. In the internal brand identity model, Serbia is recognized exclusively as a tourism destination and determined as safe and secure, hospitable, and a destination to recommend to every foreigner.

4. People. Internal stakeholders also outline members of the nation as one of the most important components of brand Serbia. The element is defined by two variables: a talent for sports and a beautiful nation, implying a different internal and external perception of the nation's features. An important role of nation members in the model was confirmed through relations with the majority of elements. Therefore, people have a direct impact on tourism and national treasures.

5. Media influence. In addition to the distorted image, domestic and foreign media's impact is recognized, which is confirmed by the direct influence of media on creating Serbia's unrealistic image. The Serbian nation shares the opinion that Serbia's image is not what is presented both by domestic and foreign media. The media also have a weaker impact on the everyday life of the nation and the presentation of treasures.

The proposed external and internal brand identity models presented a hidden structure of brand Serbia and insight into the different levels of significance of selected brand elements. Although organized brand knowledge overlaps in internal and external perception, far more important are the results that indicate a divergence in the perception of fundamental brand elements. To harmonize the differences in percep- 
tion and achieve a better position of Serbia in the consciousness of internal and external stakeholders, it is necessary to choose a set of elements that will be at- tractive to both groups. Identified brand elements are foundations for nation's competitiveness and basis for nation branding model development.

\section{Serbia nation branding model}

To materialize the concept of nation branding, the Serbia nation branding model was created (see Figure 3). The results of this research on the current state of external and internal perception of brand Serbia pointed to the following nation's competitiveness: national treasures, tourism destination, business destination and people. The identified nation's competiveness are areas on which future Serbia branding strategy should focus. Through further analysis of the nation branding model, the important role that media (local and foreign) have in representing brand Serbia, shaping the nation's image and perception internally and externally, is evident. Therefore, the creation of an adequate branding strategy for Serbia needs to rely on the media's influence.

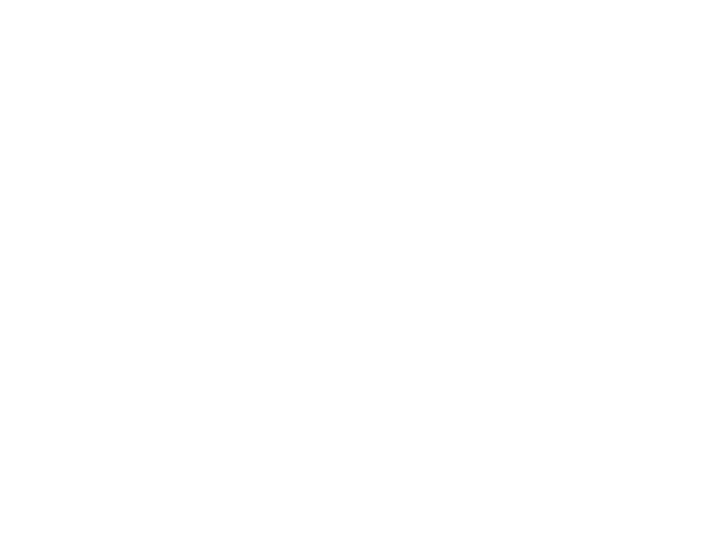

Figure 3: Nation branding model for Serbia

\section{Conclusion and discussion}

Although gaining significance over the past decade, nation branding is still a relatively new concept in Serbia that is in the initial phase. After analysing the situation in practice, it can be concluded that since gaining independence, Serbia has recognized the importance of the implementation of the nation branding concept. Moreover, initiatives have been launched to take a systemic approach to create a strategic framework, national strategy and platform at a national level that would result in concrete branding actions. However, due to the lack of understanding of the very concept, influential factors, and the need for a long-term perspective of nation branding, no initiative has taken root. Novčić Korać \& Miletić (2018) identified the following shortcomings as the main limiting factors for branding Serbia: the lack of financial backing for the branding project, pressures to achieve short-term results when there is a need for long-term investments in building a consistent nation brand, which is further reflected in sending inconsistent messages and difficulties in developing a coherent brand platform for Serbia. Today, the promotion of Serbia, as a result of the mentioned influences, boils down to presenting Serbia primarily as a tourism destination (Novčić Korać \& Šegota, 2017).

For the first time, this study gives an overview of Serbia's organized knowledge from the perspective of internal and the most important external stakeholders of Serbia. By proposing internal and exter- nal Serbia brand identity models, the most important elements of brand Serbia's hidden structure are revealed. Elements identified as the nation's competitiveness in the proposed Serbia nation branding model present core values and brand Serbia's essence. Due to the significant place that the selected elements have in the consciousness of external and internal stakeholders, Serbia can build a unique market position by focusing on the above-mentioned. It is important to note that although some elements have a more important place in the model, all nation's competitiveness must be treated equally in nation branding. By applying this approach, the elements which are currently less important in the model may, in the long run, have the desired differentiating effect in stakeholders' consciousness. In support of the conclusion, it has to be pointed out that people (members of the nation) are recognized as a brand element with the greatest potential to change the current and create the future, new image of Serbia. The proposed internal and external Serbia brand identity models and the Serbia nation branding model, can serve as a first step in the implementation of a nation branding in Serbia.

Future research on the topic of nation branding can rely on the data gained from this research and further explore whether and how perceptions change over time by exploring different time series on the same sample. Considering that this research investigates the only external perception of business class in Italy, 
Austria and Slovenia, future research should explore other stakeholder groups within each country. Finally, the future course of the research of Serbia's brand per- ception should consider widening the research sample to new countries that could become important stakeholders over time.

\section{Acknowledgments}

This research was funded through: Erasmus Mundus A2 projects - SIGMA, PhD student research, in Milan, Italy (2013-2014) and Basileus for Staff mobility in Ljubljana, Slovenia (2011); the Oead - CEEPUS Free Mover program, PhD student mobility, financed by the Austrian Federal Ministry of Science, Research and Economy, Graz, Austria (2015) and Project "Challenges and Prospects of Structural Changes in Serbia: Strategic Directions of Economic Development and Harmonization with EU Requirements" funded by Ministry of Education, Science and Technological Development of Republic of Serbia.

\section{References}

Andrei, A. G. (2017). The impact of nation branding campaigns on the country image. Case Study: Romania. Management \& Marketing. Challenges for the Knowledge Society, 12(2), 222-236.

Anholt, S. (2013). Beyond the Nation Brand: The Role of Image and Identity in International Relations. Exchange: The Journal of Public Diplomacy, 2(1), 6-12.

Aronczyk, M. (2013). Branding the Nation. The Global Business of National Identity. Oxford: Oxford University Press.

Bolin, G. (2016). The Construction of a Market for Place Branding and Public Diplomacy - A View From the North. Place Branding and Public Diplomacy, 12(2): 236-241.

Chamber of Italian-Serbian Businessmen (2015). Doing Business in Serbia. Available at: http://www. ccis.rs/?page $\mathrm{id}=343 \& \&$ mid $=11$.

Cheregi, B.F. \& Bargaoanu, A. (2020). Branding Romania as a "tech country": Nation branding in times of digital disruption. International Conference RCIC20, Cluj, Napoca.

Cvijanović, D., Simić, N., \& Vukotić, S. (2018). Creating a state brand: A brand and branding Serbia. Ekonomika, 64(2), 43-54.

Dwyer, L., Dragićević, V., Armenski, T., Mihalič, T., \& Knežević Cvelbar, L. (2016). Achieving destination competitiveness: an importance - performance analysis of Serbia. Current Issues in Tourism, 19(13), 1309-1336.

Florek, M. (2005). The country brand as a new challenge for Poland. Place Branding and Public Diplomacy, 1(2), 205-214.

Hall, D. (2002). Brand development, tourism and national identity: The re-imaging of former Yugoslavia. Journal of Brand Management, 9(4), 323-334.

Hedling, E. (2019). Storytelling in EU public diplomacy: Reputation management and recognition of success. Place Branding and Public Diplomacy, 1-10.
Kaneva, N. (2017). The Branded National Imagination and its Limits: Insights from the Post-Socialist Experience. Strategic Review for Southern Africa, 39(1), 116-138.

Konecnik, M. \& Go, F. (2007). Tourism destination brand identity: The case of Slovenia. Journal of Brand Management, 15(3), 177-189.

Malhotra, N.K. (2007). Marketing Research, An Applied Orientation, Pearson Education.

Merkelssen, H. \& Rasmussen, R.K. (2016). Nation Branding as an Emerging Field: An Institutionalist Perspective. Place Branding and Public Diploma$c y, 12(2), 99-109$.

Ministry of Foreign Affairs of the Republic of Serbia. (2014). Diaspora. Available at: http://www.mfa.gov. rs/en/consular-affairs/diaspora/diaspora-generalinformation.

Mulec, I., \& Wise, N. A. (2012). Foreign tour operators and travel agents knowledge of a potential tourism destination: the Vojvodina region of Serbia. Managing Global Transitions, 10(2).

Nath, P. (2007). MA Program 2007 - Research Methods (N1D042) Quantitative Methods 1A course handbook, Nottingham: Nottingham University Business School.

National Bank of Serbia. (2013). Godišnji izveštaj o stabilnosti finansijskog sistema. Available at: http:// www.nbs.rs/internet/cirilica/90/fs.html.

Novčić, B., Damnjanović, V. \& Popesku, M. (2012). Serbia Brand Identity: Perspectives of Residents and Diaspora. EuroMed Journal of Business, 7(3), 256-267.

Novčić, B. \& Štavljanin, V. (2015). Brendiranje nacije: Analiza brend identiteta Srbije. Časopis Marketing, 46(4), 263-275.

Novčić Korać, B., \& Šegota, T. (2017). Branding of a (desti) nation with a deteriorated image: The case of Serbia. Sociologija i prostor: časopis za istraživanje 
prostornoga i sociokulturnog razvoja, 55(1) (207), 77-99.

Novčić Korać, B. \& Miletić, B. (2018). Differential advantages of Serbia: Internal and external perspectives. Management: Journal of Sustainable Business and Management Solutions in Emerging Economies, 23(2), 27-37.

Ociepka, B. (2018). A New Brand for Postcommunist Europe. Nation Branding in Modern History, edited by C. Viktorin, JCE Gienow-Hecht, A. Estner, and M. K. Will. Berghahn Books, 197-218.

Pallant, J. (2007). Spss Survival Manual A step by step guide to data analysis using SPSS for Windows (Version 10) 2nd ed., Berkshire: Open University.

Paunović, I. (2014). Branding Serbia as a tourist destination on the global market. Turizam, 18(2), 59-71.

Pawłusz, E., \& Polese, A. (2017). “Scandinavia’s bestkept secret." $\dagger$ Tourism promotion, nation-branding, and identity construction in Estonia (with a free guided tour of Tallinn Airport). Nationalities Papers, 45(5), 873-892.

Petranović, B. (1988). Istorija Jugoslavije 1918-1988, knjiga I - Kraljevina Jugoslavija 1914-1941, Beograd: Nolit.

PKS Milano Info. (2014). Aktuealno. Predstavništvo Privredne komore Srbije $\mathrm{u}$ Italiji. Available at: http://www.pks.rs/SADRZAJ/Files/3 PKSMilanoINFO-avgust2014.pdf.

Popesku, M., Damnjanović, V., Novčić, B., \& Premović, M. (2010). Serbia as Brand - Internal Perspective.
In 3rd Annual EuroMed Conference of the EuroMed Academy of Business, Business Development Across Countries and Cultures. Nicosia, Cyprus.

Risitano, M. (2006). The role of destination branding in the tourism stakeholders system. The Campi Flegrei case. In IV International doctoral tourism and leisure colloquium. 1-18.

Saunders, R. A. (2016). Popular geopolitics and nation branding in the post-Soviet realm. Routledge.

Serbian Chamber of Commerce. (2015). Srbija otvorena za austrijske investitore, srpske firme za partnerstvo. Available at: http://www.pks.rs/Vesti. aspx?.IDVestiDogadjaji $=16959$.

Serbian Chamber of Commerce. (2013). Srbija prvi put u suficitu sa Italijom. Časopis Korak, 18-19.

SIEPA. (2014). Investirajte u Srbiju! Available at: $\underline{\text { http:// }}$ siepa.gov.rs/sr/files/pdf2010/Investirajte u Srbiju SIEPA lat dec2014.pdf.

Statistical Office of RS. (2014). Aktuelni podaci Republika Srbija. Available at: http://webrzs.stat.gov. rs/WebSite/Public/PageView.aspx?pKey=2.

Surowiec, P. (2016). Nation Branding, Public Relations and Soft Power. London \& New York: Routledge.

Szondi, G. (2007). The role and challenges of country branding in transition countries: The Central and Eastern European experience. Place Branding \& Public Diplomacy, 3, 8-20.

Volcic, Z., \& Andrejevic, M. (2011). Nation Branding in the Era of Commercial Nationalism. International Journal of Communication, 5, 598-618 